\title{
A Re-examination of U.S. High-Level Nuclear Waste Policy
}

\author{
Andrew J. Zehet
}

Andrew Zehe is enrolled in the Master of Public Administration program at The George Washington University where he is studying policy analysis. He has worked as a reports analyst at the Federal Election Commission and is currently a Graduate Teaching Fellow for the Public Administration Department.

\section{Introduction}

U.S. high-level nuclear waste policy, as articulated in the Nuclear Waste Policy Act of 1982 (NWPA), relies on geologic repositories - storage areas beneath the earth's surface that hold sealed containers of nuclear waste for eternity. The 1987 amendments to this Act (NWTAA) designate Yucca Mountain, Nevada, as the sole potential repository site. In 1998, the government is scheduled to take stewardship of commercial wastes with the opening of an interim storage facility, representing a transfer of responsibility from private industry to the federal government. A re-examination of U.S. high-level nuclear waste policy is warranted before this responsibility is assumed.

Current policy mandates government assumption of a great economic burden and a reliance on a questionable storage method while raising heated political dissent in states where storage containers will be held. In contrast, this article recommends a policy which provides for safe storage of commercial and military waste, forces nuclear power companies to pay for their waste storage, passes on the least possible burden to future generations, and limits problems of political feasibility. This policy's recommendations are as follows:

1. Continue storing those commercial wastes that are adequately contained on-site. At the same time, power companies will continue to pay into the nuclear waste fund that was created to provide funding for waste-siting. ${ }^{1}$

2. Move all military wastes and any unsafe commercial wastes into goveroment-owned, monitored, and retrievable storage facilities (MRS).

3. Eventually, move wastes stored on-site to MRS facilities.

\section{Delay opening Yucca Mountain and expand the site} selection process to consider other possible locations.

\section{Reintroduce state involvement in a voluntary site selection process.}

Admittedly, these recommendations might have the unintended consequence of forcing some nuclear power plants to close. The burden of on-site storage combined with the waste fund tax could make nuclear power unprofitable for power companies. John Castagna of the Edison Electric Institute, a trade association of investor-owned utilities, claims that the plant closings caused by these recommendations would cause a deep recession. ${ }^{2}$ However, Nicholas Lenssen, a research associate at the Worldwatch Institute, calls such claims "an idle threat" and refers to a study published in The Annual Report of the Sacramento Utilities Co. which shows that localities that have converted from nuclear power to other power sources receive a net economic benefit. ${ }^{3}$

While a discussion of the desirability or morality of nuclear power is outside this article's scope, the equity issues involved with transferring the burden of waste management from nuclear power companies to government stewardship in 1998 are worth noting.

\section{Background}

The nuclear age has presented policy-makers with the uniquely perplexing problem of nuclear waste. This problem is particularly vexing due to its long-term nature. For example, plutonium-239, a common by-product of nuclear fission, has a half-life of 24,400 years and is dangerous to humans for 250,000 years. ${ }^{4}$ Thus, policy-makers confront. problems with nuclear waste that will have effects lasting longer than the recorded history of humankind. To put this in perspective, imagine an official of Rome, a civilization 
that existed a mere (by the time scale of nuclear waste) 2,000 years ago, trying to make land-use decisions based on consequences extending into the 20th century. Clearly, nuclear waste presents a demanding challenge to today's policy-makers.

In the United States, nuclear wastes come from two sources: nuclear weapons production and commercial nuclear power generation. Although nuclear weapons production was curtailed with the end of the Cold War, a great deal of military waste already exists at sites such as Hanford, Washington, and Rocky Flats, Colorado. As of 1990, the nuclear power industry had generated an estimated 21,800 metric tons of high-level nuclear waste.5 Most of this waste takes the form of spent fuel, which is stored in cooling ponds on the grounds of nuclear power plants. On-site storage areas are feasible only as a short-term option and are beginning to reach capacity. ${ }^{6}$ Clearly, the U.S. needs a policy that addresses this situation.

Beginning in the 1960s, government officials and scientists gave serious thought to long-term waste management. Gradually, consensus around the concept of geologic repositories resulted in passage of NWPA, which set out guidelines for selection of a repository site and management of wastes that included consideration of five site locations, selection of three sites for serious examination, creation of a nuclear waste fund financed through a per-kilowatt-hour tax on electricity generated by nuclear power plants, and involvement of localities in choosing a site. In 1987, NWPAA anointed Yucca Mountain as the sole repository site for characterization (the study of a site's technical suitability). However, fierce local opposition and technical uncertainty have delayed the Yucca Mountain opening date from 2000 to 2010 and beyond.'

\section{Analytical Limits and Assumptions}

First, a discussion of the desirability or morality of nuclear weapons or nuclear power is outside this paper's scope due to the assumption that these technologies are here to stay. ${ }^{8}$ Included in this assumption is the idea that "cleaner" nuclear fusion is unlikely to be a viable power source in the foreseeable future.

Second, reprocessing (using breeder reactors to multiply a small amount of spent fuel into a self-sustaining supply of fuel) is not a desirable course of action and will not be considered. This "recycling" process creates two problems: the "increase of volume waste by 160 fold" and the proliferation of nuclear weapons.
Third, waste will be considered from a U.S. perspective. Many commentators have argued that the management of wastes should be considered an international problem (one of the benefits of such an approach being the avoidance of "not in my backyard" (NIMBY) problems). ${ }^{10}$ However, this analysis will not take an international approach because such a strategy is likely to delay resolving the waste problem and get bogged down with the question of nuclear proliferation. Also, the assertion that internationalization would ameliorate rather than exacerbate the NIMBY syndrome is questionable.

Fourth, the decision by Congress to examine only five repository sites has limited the availability of technical data. Efforts to begin gathering data on an East Coast repository were stopped by political forces, narrowing the scope of examination."

\section{Criteria}

Given the limitations of these assumptions, this paper will examine three competing policy alternatives regarding nuclear waste. To facilitate this examination, the following four criteria have been developed:

1. Effectiveness: Effectiveness will be weighted more heavily than the other three criteria, which will be weighted equally. Effectiveness is defined as the ability to contain radioactive waste without significant damage to humankind or the environment. This standard will be judged over a 10,000-year period.

2. Cost: Two cost elements will be considered. First is the expense of storage facility construction. Second is the facility's economic detriment or benefit to the surrounding locality. For example, a locality might profit from the economic activity of site construction. Part of the detrimental cost component will be stigma effects - the economic harm due to a locality's association with nuclear wastes.

3. Political feasibility: The alternative will be evaluated for its likelihood of adoption and execution on the national, state, and local levels. ${ }^{12}$ The national level will have greater bearing during the adoption phase and the state and local level greater bearing during execution.

4. Intergenerational equity: This criterion was included in recognition of the problem's long-term nature. The policy should be fair to present and future generations.

Options will be assigned a minus for poor, an $\mathrm{N}$ for neutral or a plus for good on each criterion. Further distinctions will be drawn by numerical rankings according to desirability under each criterion. 


\section{Alternatives}

Three basic alternatives will be considered: on-site storage, monitored retrievable storage (MRS) and geologic repositories.

Alternative $\# 1$ : On-site storage means that spent fuel remains in the cooling ponds of power plants. Spent fuel must be kept under water due to its extreme heat. Recently, utilities have started storing spent fuel on-site in drycask containers. For military wastes, on-site storage would mean continuing to store wastes in casks at manufacturing sites. On-site storage represents the status quo alternative.

Effectiveness: On-site storage is given a minus for effectiveness. On a short-term basis, on-site storage represents a safe option for commercial wastes. However, when judged over the 10,000-year standard, serious problems emerge. Current Nuclear Regulatory Commission standards state "that spent fuel can be safely stored without significant environmental impact for at least 100 years, if necessary."

Spent fuel exists in the form of uranium pellets stacked in fuel rods. Mary Olsen of the Nuclear Information Resource Council, an anti-nuclear group, notes that one problem associated with long-term storage is that within 100 to 500 years, these fuel rods will break apart and drop pellets to the bottom of the cooling pond or cask.1 The pellets could then "go critical" or start a meltdown. In recent years, troubling evidence has come to light about the effectiveness of military storage techniques. For example, in 1992 when plant officials discovered leakage of 7,500 gallons of waste at the Hanford plant, they were unable even to determine when the leak occurred. ${ }^{15}$ Thus, on-site storage of military waste is undesirable even in the short term.

Cost: On-site storage is given a plus for costs for two reasons. First, on-site storage, representing the status quo, would not involve construction of any new facilities. Second, wastes would be stored at facilities where they are produced so surrounding localities would not bear any additional stigma costs.

Political Feasibility: On-site storage is given an $\mathrm{N}$ for political feasibility. At the local level, this option represents the status quo and is not likely to produce more opposition than already exists. At the national level, this option is likely to be very unpopular with the nuclear industry because of the burden of storage costs. The industry would apply a great deal of political pressure against continued on-site storage.

Intergenerational Equity: On-site storage is given a minus for intergenerational equity. As shown under the effectiveness criterion, on-site storage could only promise containment in the short term for commercial waste and not at all for military waste. After on-site storage reliability breaks down, the burden of cost and containment both will have passed to another generation.

Alternative \#2: Monitored, retrievable storage (MRS) represents the interim storage measure scheduled to begin in 1998. The MRS option ships wastes to an above-ground government storage facility where they are monitored for safety. The wastes are held in cylinders that contain many redundancies of concrete and steel. Oak Ridge, Tennessee, originally was chosen to serve as an MRS site, but strong political opposition canceled these plans. Currently, the government is searching for a new site, with most efforts concentrated on finding a Native American tribe willing to accept the wastes. The Mescalero Apaches of New Mexico have received $\$ 300,000$ in grants to explore the possibility of hosting an MRS site. ${ }^{16}$ According to Maureen Conley of the Office of the Nuclear Waste Negotiator, three other tribes are considering an MRS facility: the Skull Valley Goshutes of Utah, the Fort McDermitt Paiute-Shoshone of Oregon and Nevada, and the Tonkawas of Oklahoma. ${ }^{17}$

\section{"While some proponents of Yucca Mountain maintain that the earthquake belped verify seismological models that prove the site is secure, the presence of 32 faults in the surrounding area raises serious concerns."}

Effectiveness: MRS is given an $\mathrm{N}$ for effectiveness. On a short-term basis, MRS effectiveness mirrors on-site storage. MRS is ranked higher because it offers the option of monitoring wastes and retrieving them if containment begins to break down over time. For example, a failing container could be placed inside a new container to ensure safety. Through such upgrades, MRS could possibly satisfy the 10,000-year standard. One MRS drawback is the need to transport wastes from their current locations, which involves a whole range of containment risks not associated with on-site storage.

Cost: MRS is given a minus for cost. Building and transporting a reliable storage container is very expensive. The intended facility location would gain a few employees to monitor the wastes, but these benefits would likely be canceled by the stigmatizing effects of proximity to an MRS site. In addition, MRS entails the long-term costs of monitoring the wastes. 
Political Feasibility: MRS is given a minus for political feasibility. While reaction is likely to be neutral at the national level, strong local opposition is expected. Citizens of Oak Ridge believed that, although MRS was meant as an interim measure, they were likely to be permanently stuck with the wastes.

Intergenerational Equity: MRS is given an $\mathrm{N}$ for intergenerational equity. An MRS bonus is its ability to pass on only a small concern about containment safety. A drawback to MRS is that future generations would have to pay for continued waste monitoring and correction of containment breakdowns.

Alternative \#3: Three rock types have been considered for a geologic repository - salt, basalt, and tuff. Of five sites seriously considered under NWPA, three were in salt, one was in tuff and one was in basalt. NWPAA eliminated salt and basalt repositories from consideration and called for characterization of only the tuff site, Yucca Mountain.

Tuff is a volcanic rock formed when volcanic ash settles and melts after an eruption. Yucca Mountain is in a dry, uninhabited area near U.S. nuclear weapon proving grounds. Yucca Mountain is part of the unsaturated zone - the part of the Earth's surface where water cannot move about freely and is held in place by capillary tension: (Basalt and salt sites rely on the rock type itself to keep wastes from entering groundwater.)

Effectiveness: Tuff/Yucca Mountain is given a minus for effectiveness for three reasons. First, Yucca Mountain is in a seismologically active area; a June 1992 earthquake near the site registered 5.6 on the Richter scale. ${ }^{18}$ Judy Treichel of the Nevada Nuclear Waste Task Force notes that a Department of Energy (DOE) research facility on the site was damaged by the quake. ${ }^{19}$ While some proponents of Yucca Mountain maintain that the earthquake helped verify seismological models that prove the site is secure, the presence of 32 faults in the surrounding area raises serious concerns. ${ }^{20}$

Second, human intrusion in the distant future could result in the unintentional release of radioactivity. In a recent New York Times Magazine article, Kai Erikson lists mining and dam construction as two ways in which humans might intrude on the waste site. Although the DOE discounts such scenarios, Erikson notes that:

"It is hard to take much comfort from their calculations on this score since those calculations seem to be based for the most part on the assumption that the human future will be characterized by 20 th-century political structures, 20th-century living arrangements, 20th-century thought processes and, most alarming of all, 20th-century technologies." ${ }^{21}$
Third, a dormant volcano lies just 12 miles away. Nicholas Lenssen has pointed out that although dormant for 20,000 years, "volcanic activity could easily resume in the area before Yucca Mountain's intended lethal stockpile is inert." 22 In Yucca Mountain's favor is its remoteness from groundwater (1,800 feet below) and human populations. Still, weighing various pluses and minuses gives Yucca Mountain an overall minus.

Cost: Tuff/Yucca Mountain gets a minus for cost for two reasons. First, the cost of researching, mining and transportation for any repository site is extremely high. Tuff is a hard rock form which further raises the costs of construction. Although land is not expensive near Yucca Mountain, it is difficult and expensive to build a repository given the hardness of tuff. Second, Nevada's economy is centered largely around gambling and tourism. The effects of a repository could particularly harm these industries.

Political Feasibility: Tuff/Yucca Mountain gets an $\mathrm{N}$ for political feasibility. At the national level, a general consensus has already grown around Yucca Mountain. Nevada's small congressional contingent has failed to reverse this consensus. At the state level, opposition is strong, but there is some sense of inevitability about the repository's eventual construction.

\begin{tabular}{c}
\hline "If containment proved \\
ineffective, ... the generation \\
that chose a geological repository \\
would long be dead, leaving the \\
burden to generations that bad \\
no say in the choice and no way \\
to relocate the waste easily."
\end{tabular}

Intergenerational Equity: Tuff/Yucca Mountain gets a minus for intergenerational equity. While the costs of a repository would be borne primarily by the constructing generations, the reliability of radiation containment is troubling. If containment proved ineffective, the breakdown costs most likely would be borne by future generations due to the long period of time necessary for radiation leaks to reach groundwater and enter the food chain. By that time, the generation that chose a geological repository would long be dead, leaving the burden to generations that had no say in the choice and no way to relocate the waste easily. As Kai Erikson wrote of future generations, "we are not taking the problem out of their hands so much as we are taking the solution out of their hands. ${ }^{n 3}$ 


\section{Ranking Process}

Ranking the various options to draw distinctions within the same rating level will be helpful. In explaining the ranking process, only those categories that received the same mark (minus, $N$, or plus) will receive comment:

Effectiveness. The three options were ranked as follows for effectiveness: MRS, on-site, and tuff/Yucca Mountain. On-site storage ranked ahead of tuff/Yucca Mountain because it offered relatively secure short-term containment and did not involve waste transportation and related risks.

Cost. The three options were ranked as follows for costs: on-site ranked first and MRS and tuff/Yucca Mountain tied. Construction of an MRS facility was clearly cheaper than a geological repository, but the long-term costs of monitoring an MRS facility likely would balance construction costs.

Political Feasibility. The three options were ranked as follows for political feasibility: on-site, tuff/Yucca Mountain, and MRS. On-site storage ranked ahead of tuff/ Yucca Mountain because it represents the status quo and is unlikely to arouse new waves of opposition.

Intergenerational Equity. The three options were ranked as follows for intergenerational equity: MRS, tuff/Yucca Mountain, and on-site storage. Tuff/Yucca Mountain was chosen before the on-site location because, despite serious containment problems, this alternative at least avoids the on-site storage problem of passing economic costs to future generations.

\section{Boxscore}

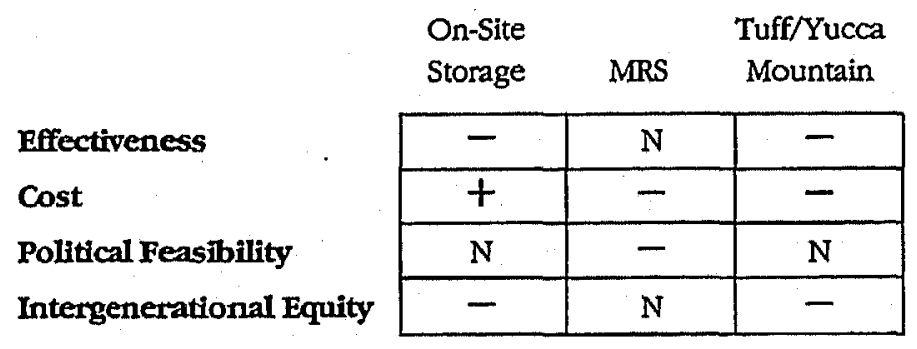

Effectiveness

1. MRS

2. On-site

3. Tuff/Yucca Mtn.

Political Feasibility

1. On-site

2. Tuff/Yucca Mtn.

3. MRS

\section{Cost}

1. On-site

Tied $\left\{\begin{array}{l}\text { 2. MRS } \\ \text { 2. Tuff/Y }\end{array}\right.$

2. Tuff/Yucca Mtn.

Intergenerational Equity

1. MRS

2. Tuff/Yucca Mtn.

3. On-site

\section{Synthesis}

When examining different alternatives under the criteria, it is striking how poorly each fared. Only one plus rating was assigned in the entire analysis and that went to on-site storage under the cost criterion. Under the most important criterion, effectiveness, MRS was the only alternative that did not receive a minus rating. This analysis shows the poverty of our present high-level radioactive waste policy. Several conclusions and recommendations can be drawn from this analysis.

Overall, MRS, the top performer in terms of effectiveness (the most important criterion) and intergenerational equity, appears to be the best option. For cost, this option was given a minus, but still ranked second. Only in terms of political feasibility did MRS rank last.

In addition to ranking first for both cost with a plus and political feasibility with an $\mathrm{N}$, on-site storage showed short-term promise for effectiveness. The major faults of on-site storage are long-term effectiveness and intergenerational equity.

The geological repository, tuff/Yucca Mountain, scored extremely poorly (receiving as a high mark an $\mathrm{N}$ for political feasibility) and represents the least effective and most expensive option. For intergenerational equity, tuff/ Yucca Mountain ranked ahead of on-site storage by not transferring economic burdens. Clearly, the central role Yucca Mountain plays in U.S. nuclear waste policy should be reconsidered.

Given these facts, the following hybrid policy is recommended:

1. Continue storing those commercial wastes that are adequately contained on-site. At the same time, power companies should continue to pay into the nuclear waste fund. If the government takes stewardship, the cost of monitoring waste and cleaning up any containment breakdown would be, in effect, a taxpayer-funded liability. In contrast, under this recommendation power companies must bear storage burdens.

2. Move all military wastes and any unsafe commercial wastes into a government-owned MRS facility, ensuring containment of the greatest short-term risks. A hint at where to locate such facilities comes from Sweden, which has located an interim facility "adjacent to an existing reactor, in recognition that communities with the experience of hosting a nuclear plant tend to be more willing to accept waste storage facilities. ${ }^{\text {"2 }}$ 
3. Eventually move wastes stored on-site to the MRS facility. This step will ensure that on-site wastes are moved before expiration of the short-term containment value of on-site storage. In the meantime, sufficient funds should have accumulated in the nuclear waste fund to pay for expansion of the MRS facility and to help future generations cover the costs of monitoring.

4. Delay opening the Yucca Mountain repository and reopen the site selection process so that data on other potential sites can be gathered. As prospects of opening Yucca Mountain have dimmed, some scholars have begun noting that "no compelling reason currently exists for siting a permanent repository at an early date."3s By keeping wastes on-site and at MRS facilities, the policy will be adaptable if emerging technologies such as transmutation - a chemical process that transforms the wastes into less dangerous isotopes - prove promising in the future. ${ }^{26}$ At the same time, examining other potential repository sites will help ensure that a repository is chosen on merit rather than political expediency (as some have charged in the case of Yucca Mountain and NWPAA).

5. Reintroduce state involvement in a voluntary siting process. Most commentators, regardless of their opinions about the technical merits of waste storage techniques, agree that the primary obstacle to U.S. waste policy is public unease with things nuclear. ${ }^{27}$ Opening up the site selection process to allow state involvement, as originally intended under NWPA, would begin to build public trust. One small step in this direction would be congressional reauthorization of the Nuclear Waste Negotiator whose office expires in 1995..$^{28}$

These recommendations are an improvement over current policy. They capitalize on the short-term merits of on-site storage and avoid early transference of a huge economic burden to the government. At the same time, they present a reasonable option to pay for construction of an MRS site.

Another attractive feature of this policy option is that even its weaknesses - in the areas of intergenerational equity and political feasibility - are not severe. While this policy passes some of the nuclear waste burden to future generations, funding for monitoring wastes is provided. In addition, this policy offers greater flexibility than a geologic repository to change waste handling procedures. The political feasibility of any off-site storage was shown in the analysis to be poor; however, placing the MRS facility near existing nuclear facilities might lessen some opposition, as in the Swedish experience. Additionally, this policy might appeal to anti-nuclear and environmental groups, given the costs borne by the nuclear power industry as noted in the introduction.

When asked to comment on these recommendations, Edison Electric's John Castagna, believing that the site selection process was already fraught with bureaucracy and moved too slowly, said he was "very surprised." ${ }^{29}$ In contrast, Worldwatch's Nicholas Lenssen found these recommendations "more rational than the current process."30

In conclusion, the difference between these policy recommendations and the current U.S. policy is clear. Current policy involves the government's assumption of a great economic burden and reliance on a questionable storage method, while raising great political dissent in repository states. In contrast, these recommendations provide safe storage of commercial wastes, force nuclear power companies to pay for their wastes, ensure that military wastes are safely contained, pass on the least possible burden to future generations and limit problems of political feasibility. Therefore, the recommendations seem an improvement over present policy.

Kai Erikson summarized the value of such an approach:

Perhaps the Government should relax its insistence on immediate and irreversible burial and turn to forms of storage that allow both continuous monitoring and retrieval. In the face of all the doubts and uncertainties that attend nuclear waste management, such a policy maximizes flexibility and keeps options open."

Bob Loux, executive director of the Nevada Nuclear Waste Project Office, echoed this sentiment, saying:

The Nuclear Regulatory Commission has determined that waste can be safely stored above ground for at least a century. During that time we should institute a nationwide program to develop a safe and lasting solution - a Manhattan Project in reverse, if you will..$^{32}$

These recommendations would require congressional action. Although Congress is reluctant to revisit the difficult issues of nuclear waste policy, Sen. Paul Wellstone (D-MN) has been circulating among his Senate colleagues a letter to President Clinton that calls for just such a re-examination. ${ }^{33}$ Many of the concepts contained in the letter, such as greater state involvement in the siting process, are consistent with the recommendations contained in this analysis. ${ }^{34} *$ 


\section{Notes}

$\dagger_{I}$ wish to thank the following for their advice and patience: Linda Parham, Mike Parks, and Mary Bounds. Your contributions to this article are greatly appreciated.

1 This fund was created under NWPA. It is financed through a per-kilowatt-hour tax paid on electricity generated by nuclear power plants.

2 John Castagna, telephone interview by author, 4 March 1994, Washington, D.C., Edison Electric Institute, Washington, D.C.

3 Nicholas Lenssen, telephone interview by author, 4 March 1994, Washington, D.C., Worldwatch Institute, Washington, D.C.

4 Nicholas Lenssen, Nuclear Waste: The Problem that Won't Go Away (Washington, D.C.: Worldwatch Institute, 1991), 9. A half-life is the "time required for a radioactive substance to lose 50 percent of its activity by decay." League of Women Voters, The Nuclear Waste Primer (New York, NY: Lyons \& Buford, 1993) 158.

5 This amount is projected to grow to 40,400 metric tons by the year 2000. Ibid., p.12.

${ }^{6}$ Luther Carter notes that in recent years the spacing required between spent fuel assemblies has been shrunk from 20 to 12 inches to make room for more fuel than was anticipated for. Luther J. Carter., Nuclear Imperatives and Public Trust (Washington, D.C.: Resources for the Future, 1987), p. 17. Transferring these wastes to government stewardship would clear the cooling ponds and enable porver companies to produce more wastes that would presumably also come under govemment stewardship.

7In addition, Sen. Bennett Johnston (D-LA) points out that over ten years the estimated costs of site characterization have risen from between $\$ 40-100$ million to $\$ 6$ billion. Congress, Senate, Committee on Energy and Natural Resources, Department of Enengy's Civilian Nuclear Waste Program, 102nd Cong., 2nd sess., 31 March 1992, p.34.

8 In anticipation of criticism of this assumption, it is noted that sufficient stockpiles of waste already exist to require a waste policy.

9 Some nations (India and now North Korea) have used "peaceful ${ }^{n}$ power industries and reprocessing to advance their nuclear weapons programs. Nicholas Lenssen, Nuclear Waste the Problem that Won't Go Away, pp. 22, 32.

10 Wolf Hafele, "Energy from Nuclear Power," Scientific American September 1990, pp. 137-144.

11 It is worth noting the validity of one of the arguments used by opponents of an East Coast repository: the East's denser population would greatly increase the impact of any containment breakdown.

12 The history of facility siting has shown a consistent and strong resistance at the state level. In rare instances, support exists at the local level but has not been statewide.
13 Federal Register, 18 September 1990, p. 38513.

14 Mary Olsen, interview by author, 23 November 1993, Washington, D.C., Nuclear Information and Resource Council, Washington, D.C.

15 Matthew L. Wald, "Deadly Waste Seems to Have Leaked in Washington State," New York Times, 28 February 1992, sec. 1, p.31.

16 Thomas W. Lippman, "On Apache Homeland, Nuclear Waste Seen as Oppontunity," Washington Post, 28 June 1992, sec. A, p. 3.

17 Maureen Conley, telephone interview by author, 11 March 1994, Washington, D.C., Office of the Nuclear Waste Negotiator, Washington, D.C.

18 Sandra Blakeslee, "Earthquake Raises Concern About Nuclear Waste Dump," New York Times, 4 July 1992, sec. 1, p. 6.

19 Judy Treichel, telephone interview by author, 7 March 1994, Washington, D.C., Nevada Nuclear Waste Task Force, Nevada.

${ }^{20}$ Sandra Blakeslee, "Earthquake Raises Concèrn About Nuclear Waste Dump," New York Times, 4 July 1992, sec. 1, p. 6.

21 Kai Erikson, "Out of Sight, Out of Our Minds," New York Times Magazine, 6 March 1994, p. 50.

22 Nicholas Lenssen, "Facing Up To Nuclear Waste," WorldWatch, March/April 1992, p. 12.

23 Erikson, p. 63.

24 James Flynn, Roger Kasperson, Howard Kunreuther and Paul Slovic, "Time to Rethink Nuclear Waste Storage," Issues in Science and Tecbnology, Summer 1992, p. 45. In addition, such near plant siting would resolve some of the equity issues with placing the wastes in Yucca Mountain. Nevadans who oppose Yucca Mountain are fond of pointing out that they bear the burden of waste management, but do not contribute to the production of the waste (no nuclear power plants are located in Nevada).

25 Ibid., p.43.

26 Ibid.

27 This unease is likely to be raised, at least in the short term, by the recent revelations about nuclear experiments and previously undisclosed nuclear bomb tests.

28 Maureen Conley, telephone interview by author, 11 March 1994, Washington, D.C., Office of the Nuclear Waste Negotiator, Washington, D.C.

29 John Castagna, telephone interview by author, 4 March 1994, Washington, D.C., Edison Electric Institute, Washington, D.C. 
30 Nicholas lenssen, telephone interview by author, 4 March 1994, Washington, D.C., Worldwatch Institute, Washington, D.C.

31 Erikson, p. 63.

32 Press release, Kamer/Singer \& Associates, 25 February 1994, p.3.

33 "Senate Democrats Want Re-Evaluation of Radioactive Waste Policy," Nuclear Monitor, Vol.9, No. 1 (1994): p.1.
34 As of this writing, twelve Senators (Wellstone, Boxer, Metzenbaum, Bryan, Reid, Murray, Jeffords, Kerry, Feingold, Leahy, Kohl and Levin) have signed the letter which was scheduled to be presented to President Clinton in early March. Paul David Wellstone, U.S. Senator, personal letter to President Clinton, 1 February 1994, Washington, D.C.; Ken Boley, telephone interview by author, 3 March 1994, Washington, D.C., U.S. Senator Wellstone's staff, Washington, D.C.

\section{Bibliography}

American Nuclear Energy Council, "High-Level Nuclear Waste and the Yucca Mountain Project," Issue Brief, May 1993.

Blakeslee, Sandra, "Earthquake Raises Concern About Nuclear Waste Dump," New York Times, 4 July 1992, sec. 1, p. 6.

Congressional Quarterly Almanac, "Comprehensive Nuclear Waste Plan Enacted." (1982): pp. 304-310.

Boley, Ken, Office of Senator Paul David Wellstone, interview by author, 3 March 1994, Washington, D.C.

Carter, Luther J., Nuclear Imperatives and Public Trust, Washington, D.C.: Resources for the Future, 1987.

Castagna, John, Edison Electric Institute, interview by author, 4 March 1994, Washington, D.C.

Conley, Maureen, Office of the Nuclear Waste Negotiator, interview by author, 11 March 1994, Washington, D.C.

Easterling, Douglas, "Fair Rules for Siting a High-Level Nuclear Waste Repository," Journal of Policy Analysis and Management, Vol. 11, No. 3 (1992): pp. 442-475.

Erikson, Kai, "Out of Sight, Out of Our Minds," New York Times Magazine, 6 March 1994, 34-41, pp. 50, 63.

Federal Register, "Consideration of Environmental Impacts of Temporary Storage of Spent Fuel After Cessation of Reactor Operation; and Waste Confidence Decision Review; Final Rules," 18 September 1990 , p. 29181.

Flynn, James, "How Not to Sell a Nuclear Waste Dump," Wall Street Joumal, 15 April 1992, sec. A, p. 20.

Flynn, James, Roger Kasperson, Howard Kunreuther, and Paul Slovic, "Time to Rethink Nuclear Waste Storage," Issues in Science and Technology, Summer 1992: pp. 42-48.

Flynn, James, and Paul Slovic, "Nuclear Waste and Public Trust," Forum for Applied Research and Public Policy, Spring 1993: pp. 92-101.

Gregory, Robin, and Sarah Lichtenstein, "A Review of the High-Level Nuclear Waste Repository Siting Analysis," Risk Analysis, Vol. 7, No. 2 (1987): pp. 219-225.
Hafele, Wolf, "Energy from Nuclear Power," Scientific American, September 1990: pp. 137-144.

Jacob, Gerald, Site Unseen: The Politics of Siting a Nuclear Waste Repository, Pittsburg, PA: University of Pittsburg Press, 1990.

Kamer/Singer Associates, Press Release, Las Vegas Nevada, 25 February 1994.

Keeney, Ralph L., "An Analysis of the Portfolio of Sites to Characterize for Selecting a Nuclear Repository," Risk Analysis Vol. 7, No. 2 (1987): pp. 195-218.

League of Women Voters Education Fund, The Nuclear Waste Primer, New York, NY: Lyons \& Buford, 1993.

Lemmons, John, and Charles Malone, "High-level Nuclear Waste Disposal and Long-term Ecological Studies at Yucca Mountain," BioScience, Vol. 41, No. 10 (1991): pp. 713-718.

Lenssen, Nicholas, Nuclear Waste: the Problem That Won't Go Away, Worldwatch Paper No. 106, Washington, D.C.: Worldwatch Institute, December 1991.

Lenssen, Nicholas, "Facing Up to Nuclear Waste," Worldwatch, March/April 1992, pp. 10-17.

Lenssen, Nicholas, Worldwatch Institute, interview by author, 4 March 1994, Washington D.C.

Lippman, Thomas W., "The Federal Page-Tribe Considers Nuclear Dump; Application for Study Grant is First Under Energy Dept. Program," Washington Post, 21 October 1991, sec. A, p. 17.

, "Geological Survey Shifts Nuclear Work; Changes Preserve Interagency Comity," Wasbington Post, 2 April 1991, sec. A, p. 19.

"On Apache Homeland, Nuclear Waste Seen as Opportunity," Washington Post, 28 June 1992, sec. A, p. 3.

, "Temporary Nuclear Waste Storage Site Sought: Energy Department Concedes It Cannot Meet 1998 Deadline for Permanent Facility," Washington Post, 19 December 1992, sec. A, p. 4. 
, "Storage Problem Looms on Nuclear Waste Fuel;

Clinton May Have To Make Disposal Decision, ${ }^{\text {W Washington }}$ post, 2. February 1993, sec. A, p. 9.

Lowry, David, "2010: America's Nuclear Waste Odyssey," New Scientist, 6 March 1993, pp. 30-33.

Maclean, Douglas, "Radioactive Wastes: A Problem of Morality Between Generations," in Equity Issues In Radioactive Waste Management, Roger E. Kaperson, ed, pp. 175-188. Cambridge, Mass.: Oelgeschlager, Gunn \& Hain, 1983.

Merkhofer, Miley W., and Ralph L. Keeney, "Multiattribute Utility Analysis of Alternate Sites for the Disposal of Nuclear Waste," Risk Analysis, Vol. 7, No. 2 (1987): pp. 173-194.

Nuclear Monitor, "Senate Democrats Want Re-evaluation of Radioactive Waste Policy," Vol. 9, No. 1 (1994): pp. 1, 3-4.

Olsen, Mary, Nuclear Information and Resource Council, interview by author, 23 November 1993, Washington, D.C.

Olsen, Mary, Nuclear Information and Resource Council, interview by author, 7 February 1994, Washington, D.C.

Perry, Pete, Office of Senator Paul David Wellstone, interview by author, 9 February 1994, Washington, D.C.

Salpukas, Agis, "U.S. Hopes for Breakthrough on Atomic Waste Site", New York Times, 13 April 1993, sec. A, p. 16.
Shrader-Frechette, Kristin, "Ethical Dilemmas and Radioactive Waste: A Survey of the Issues," Environmental Etbics, Winter 1991: pp. 327- 343.

Sigmon, E. Brent, "Achieving A Negotiated Compensation Agreement In Siting: The MRS Case," Journal of Policy Analysis and Management, Vol. 6, No. 2 (1987): pp. 170-179.

Treichel, Judy, Nevada Nuclear Waste Task Force, interview by author, 7 March 1994, Washington, D.C.

U.S. Congress, Senate, Committee on Energy and Natural Resources, Department of Energy's Civilian Nuclear Waste Program, 102nd Cong., 2nd Sess., 21 March 1992.

U.S. Congress, Senate, Committee on Energy and Natural Resources, Department of Energy's Civilian Nuclear Waste Program, 102nd Cong., 2nd Sess., 31 March 1992.

U.S. Department of Energy, Office of Civilian Radioactive Waste Management, DOE's Yucca Mountain Studies, Washington, D.C.: U.S. Government Printing Office, 1990.

Wald, Matthew L., "Deadly Nuclear Waste Seems to Have Leaked in Washington State", New York Times, 28 February 1993, sec. 1, p. 31.

Wellstone, Paul, Letter from Senator Paul David Wellstone to President Bill Clinton, 1 February 1994. * 